Article

\title{
Ecocritical Engagement with Picturebook through Literature Conversations about Beatrice Alemagne's On a Magical Do-Nothing Day
}

\author{
Nina Goga ${ }^{1, *}$ and Maria Pujol-Valls ${ }^{2}$ \\ 1 Department of Language, Literature, Mathematics and Interpreting, Faculty of Education, Arts and Sports, \\ Western Norway University of Applied Sciences, 5063 Bergen, Norway \\ 2 Department of Education, Faculty of Education Sciences, Universitat Internacional de Catalunya, \\ 08195 Sant Cugat del Vallès, Spain; mpujolv@uic.cat \\ * Correspondence: Nina.Goga@hvl.no
}

Received: 29 July 2020; Accepted: 14 September 2020; Published: 16 September 2020

\begin{abstract}
This article addresses the need for student teachers to experience how to engage ecocritically with children's literature to be able to support and develop the sustainability competencies of their future students. In order to respond to this need, we designed a research project examining how Norwegian and Catalan student teachers express and negotiate their ideas about an Italian-French picturebook in a teacher-researcher designed ecocritical literature conversation (ELC). The collected material, consisting of students' notes and sound recorded and transcribed group discussions, was analysed following the steps of content analysis with an emphasis on finding evidence of dialogic competencies and ecocritical competencies. Although the students did not explicitly integrate ecocritical terminology in their discussions, we found that when structured in line with ideas of dialogic teaching, ecocritical thinking, and literature didactics, literature conversations proved to be a useful tool for these students to critically engage with and negotiate about representations of nature and ecological wisdom from the selected picturebook.
\end{abstract}

Keywords: ecocritical literature conversation; Sustainable Development Goals; dialogic competency; ecocritical competency; critical thinking; teacher education; picturebook; Beatrice Alemagna

\section{Introduction}

A recent Norwegian study revealed that even though literature plays an important role in Language Arts education in school, little time is spent on students' own discussions on literature [1]. Most of the work related to literature consists of tasks about genre characteristics and detecting literary devices. To secure future students' access to more varied ways of engaging with literature, student teachers need to experience and learn about these manifold approaches and perhaps particularly to experience [2] and learn how to implement literature discussions and conversations so that when they become teachers, their pupils become familiar with these activities.

Engaging with literature through dialogue and discussion can serve various purposes. One is to activate literary concepts in analytical approaches to text [3], and another is to identify specific themes and questions at stake in the text and discuss them in relation to the readers' own lives [4]. A third purpose is to explore and experience how dialogues and discussion related to literature may enrich, challenge, or adjust one's assumptions about and interpretations of the text [5]. Hence, dialogues can impart or improve the negotiation and meaning-making skills of those who take part in the dialogue.

Skills like that of critically engaging with text and sharing and negotiating meaning are not only needed when exploring literature, they are also recognized as key competencies in other contexts [6,7]. 
One such context is that of education for sustainability (EDS). Among the eight cross-cutting key competencies for achieving the Sustainable Development Goals (SDGs) identified by the United Nations, we find collaboration competency and critical thinking competency [8] (p. 10). According to the $\mathrm{UN}$, collaboration competency is the set of "abilities to learn from others; to understand and respect the needs, perspectives and actions of others (empathy); to understand, relate to and be sensitive to others (empathic leadership); to deal with conflicts in a group; and to facilitate collaborative and participatory problem solving" [8] (p. 19), and critical thinking competency is "the ability to question norms, practices and opinions; to reflect on own one's [sic] values, perceptions and actions; and to take a position in the sustainability discourse" [8] (p. 10). In the light of recent and distinctive changes in several school curriculums around Europe which especially emphasize the need to facilitate involvement and participatory learning and to teach sustainable development across school subjects, one may argue that it could be both feasible and desirable to combine literature discussions with EDS and the UN's key competencies for achieving the SDGs.

The Catalan Curriculum for Primary Education [9] states that teachers need to promote the involvement of each student in their learning process. One of the basic competencies is learning-to-learn, described as the ability to undertake, organize, and lead learning individually or in groups. The Catalan curriculum also reports that knowledge of the environment should allow students to focus on improving their environment and making it sustainable. Additionally, one of the key contents for the Environment Knowledge Area is biodiversity and sustainability. In the same way the Norwegian core curriculum for primary and secondary education builds on the idea of learning to learn and states that by "reflecting on learning, both their own and others', the pupils can gradually develop an awareness of their own learning processes" [10]. By autumn 2020, sustainable development will be one of three interdisciplinary topics in school, which implies that students, through dialogue and critical engagement with text, shall develop knowledge about how texts represent nature, the environment, and the conditions of life, both locally and globally [11].

This article presents and discusses the findings of a cross-national study focusing on how Norwegian and Catalan student teachers express and negotiate their ideas about an Italian-French picturebook in a teacher-researcher designed ecocritical literature conversation (ELC). Due to the theoretical framework of the literature conversation, the study also examines whether the ELC allowed these students to share ideas with others to build an analysis and understanding of the picturebook from an ecocritical point of view. We will first briefly present previous research on literature conversations with students in higher education. Then we will clarify the theoretical background of ecocritical literature conversations before presenting both method and material. Finally, and in line with the theoretical background and the method applied to the material, we will present, analyse, and discuss our findings.

\section{Previous Research on Literature Conversations and Text-Talk in Higher Education}

As pointed out by Maritha Johansson [3], although several studies have addressed various aspects of literary text-talks in schools, only a few studies have been concerned with literary text-talks in higher education. While Johansson has studied "how some students' reception of a poem is influenced by their interaction with each other" [3] (p. 62) and whether "the students use a set of literary conceptual tools when they talk about the poem" [3] (p. 62), another research team [5] has studied the same text-talks to find out how student teachers build ideas about a literary text and how they work towards an overall conception of the text. Lykke Guanio-Uluru [4] carried out a research project on literature circles with student teachers focusing on ecocritical aspects of literary texts. Her aim was to determine whether tailored literature circles "would make student-teachers aware of how they can use literature as a process to reflect on sustainability" [4] (p. 5). An intervention was implemented in the teacher-training classroom and a pre-test and a post-test were used to detect its impact on students.

While none of the studies mentioned dealt specifically with children's literature or with the usefulness of text-talks to challenge students' initial ideas about the topic of the books, Jill M. 
Hermann-Wilmarth's [12] study of text-talks with preservice elementary school teachers uses "a Freirean dialogic structure during book discussions to push students past their initial resistance to the topic [gay and lesbian children's literature] and toward thinking about the children that they could face in their classrooms" [12] (p. 189). The Freirean approach implies that to listen to one another is an exercise in recognition [12] (p. 189). By analysing the small-group discussions and focusing on the ways that dialogic interaction added complexities to the students' views on the topic of the book, Hermann-Wilmarth finds that students teased "out each other's thinking" [12] (p. 191) and that the dialogic structure helped students "to step out of their 'circle of certainty'" [12] (p. 191).

The text-talks building the material of our study closely focus on the picturebook through reading aloud and sharing text and illustrations in class. Our study of these text-talks aims at finding out how the student teachers express and negotiate their ideas about the picturebook in ecocritical literature conversations. In addition, it may also provide information or knowledge about whether ELCs may be a place for critical exploration of nature connectedness.

\section{Theoretical Framework}

Although William Rueckert [13] is known as the one that coined the concept of ecocriticism, the mid-1990s is recognized as the main starting point for ecocriticism or the ecocritical approach to literature. Additionally, it should be noted that the ecocritical turn did not arise in a vacuum. Aristotelian nature knowledge, the environmental thoughts of Virgil, Rousseau's education in nature, Thoreau's life in the woods, and Carson's worries about the silent springs are all important Western pre-texts to the idea of ecocriticism as presented in The Environmental Imagination [14] and in The Ecocriticism Reader [15]. One of the most cited definitions of ecocriticism is found in Glotfelty's introduction and reads "ecocriticism is the study of the relationship between literature and the physical environment" [16] (p. xviii). Glotfelty further underscores that "ecocriticism takes an earth-centered approach to literary studies" [16] (p. xviii). Another main source following Glotfelty's definition is Greg Garrard, who explains ecocriticism as "the study of the relationships between the human and the non-human, throughout cultural history and entailing critical analysis of the term 'human' itself" [17] (p. 5). Building on these key texts within ecocriticism, we may list a set of questions appropriate for the study of children's literature from an ecocritical perspective. The questions most relevant to the design of the ecocritical literature conversation in the present study are: How is nature represented in words and illustrations? What role does the physical setting play in the plot of this picturebook? Are the values expressed in this picturebook consistent with ecological wisdom?

In the wake of a growing number of ecocritical approaches to (children's) literature, the question arises of what might characterize ecocritical didactics or pedagogy. A key challenge within the field is to find the balance between the ethical dimension of ecocriticism and the emphasis on critical thinking within the humanities. According to Sieglinde Grimm [18], ecocriticism and ecopedagogy should focus on "the relationship between man and nature as it is shown in literary texts" [18] (p. 256) to become aware that literature is mainly "a demonstration of basic cultural patterns of what we experience in our lives" [18] (p. 256).

Another way to conceptualize ecopedagogy is put forth by Greta Gaard. According to Gaard [19] (p. 326), ecopedagogy seeks to foster environmental literacy, which is ecological knowledge from a local to a global perspective, to accentuate so-called "cultural ecoliteracy." Cultural ecoliteracy should be understood as a critique of non-sustainable cultures and studies. Hence, Gaard sees ecopedagogy as a visionary activism that can mobilize and engage humans towards balance and equality across various forms of life.

Dialogic teaching has been defined as "a kind of teaching in which talk is given the prominence which effective thinking and learning require" [20] (p. 9) because it "harnesses the power of talk to engage children, stimulate and extend their thinking, and advance their learning and understanding" [20] (p. 37). The main elements that define this approach are collectivity, reciprocity, support, cumulation, and purposefulness. The teacher plans and guides a classroom talk with a didactic purpose in which 
teachers and children work together to listen to each other and learn from each other's points of view, without the fear of giving wrong answers, so different ideas become chained.

In these conversations, participants can develop and show their critical thinking. Tung and Chang [21] (p. 291) argue that one of the capacities that demonstrate this skill is being able "to find out the causal relationship of the connections between the events or actions." Similarly, Paul [22] (p. 17) argues that skilled critical thinkers have "an ability to formulate, analyze, and assess [...] inferences, reasoning, and lines of formulated thought, and implications and consequences that follow."

When these dialogues or talks revolve around literature, participants express their reading experiences with the purpose of examining literary texts, exchanging opinions and negotiating meaning $[23,24]$. Literary dialogues or conversations embrace Neil Mercer's concept of interthinking $[25,26]$. These authors argue that language can be used to think collectively in order to make sense of experiences and solve problems. If we know how human beings use language to cover practical and social needs for individual citizens or communities, we will know how to use our intellectual resources more efficiently. In the same vein, Aidan Chambers has widely defended children's booktalks organized as "a community of readers whose mutual interest is focused by a shared text," guided by a supportive adult [27] (p. 13). He asserts that with these conversations "we come to a 'reading' - a knowledge, understanding, appreciation—of a book that far exceeds what any other member of the group could have achieved alone" [27] (p. 17). Moreover, by learning how to talk about books, we also learn to think and talk about other matters. Equivalently, Littleton and Mercer argue that "thinking collectively provides a template for thinking alone" [26] (p. 112).

Literary conversations have some connections with literature circles, although the main difference is that participants in literature circles adopt different roles, such as being in charge of choosing important words, selecting key passages and preparing general reflective questions [28]. Instead of assigned reading roles as an entrance to the texts, literature conversations may be designed in line with both Judith Langer's [29] four stances (without any set linearity) of understanding literature and Alice Curry's scaled reading [30]. Langer's stances differentiate between ways of being out of, stepping into, moving through and stepping out of the text [29] (pp. 57-59), and Curry's scaled reading involves being aware of the different responsibilities and possibilities offered by a text to create change. When Curry considers the possibility of applying scaled reading to children's literature, she argues that acknowledging the human responsibility towards the earth is absolutely necessary.

On the basis of the ideas related to ecocriticism, ecopedagogy, dialogic teaching, and ways of reading and understanding literary texts, it can be argued that dialogic teaching can particularly be used as a suitable way to achieve critical explorations in literature conversations and, more specifically, in ecocritical literature conversations (ELCs). An ELC is an ecodialogic space for students to analyse, discuss, think together, and negotiate the meaning of a literary work from an ecocentric perspective.

\section{Material, Design and Method}

The empirical material for this study is collected in two ELCs about the picturebook Un Grand Jour de Rien (2016, On a Magical Do-Nothing Day) by the Italian-French artist Beatrice Alemagna. The picturebook was translated into Catalan in 2016. It has not been translated into Norwegian. The book was presented to the Norwegian students in a translation by Nina Goga. (For details about the translation from French and Italian to English, see [31].) The material collected consists of two sound recorded and transcribed group discussions as well as students' notes written during the ELC-lesson and submitted with the digital tool Talkwall (also called Samtavla). The design of the project was approved by the Norwegian Centre for Research Data (NSD) and by the Research Ethics Committee of the Universitat Internacional de Catalunya. All data was stored in accordance with NSD's requirements and at the institutional digital research archive platforms.

The ELCs took place during the spring term 2020 in two student teacher classes on literature and language, one in Norway and one in Catalonia (see Table 1 below). The students were recruited by the teacher-researcher in class. All students were informed about the ELC project in class, in messages to the 
students and in information letters. Fully aware of the possible power imbalance between teacher and student teachers, and the ethical challenges of doing research in one's own class, the teacher-researchers made it especially clear in their communication with the students that although they all had signed consent letters, they had the possibility to withdraw their consent at any time during the research process. The involved students have also been given the chance to comment on the use of the recorded and written material in this article. The Norwegian students willing to participate were part of a larger group of students and the lesson was part of a one-day literature laboratory focusing on different didactic approaches to literature. Hence, some students participated in the ELC without being part of the data collection. The Catalan students belonged to a group of four students only. All of them agreed to participate in the project.

Table 1. Presentation of Participants.

\begin{tabular}{|c|c|c|c|c|}
\hline $\begin{array}{l}\text { Ecocritical Literature } \\
\text { Conversations (ELC) }\end{array}$ & Country & $\begin{array}{l}\text { Number of } \\
\text { Participants }\end{array}$ & Education & $\begin{array}{c}\text { Duration of } \\
\text { Lesson/Recorded Talk }\end{array}$ \\
\hline ELC 1 & Norway & 6 & $\begin{array}{l}\text { 3rd-year student in Master's } \\
\text { 5-Year Programme in Teacher } \\
\text { Education, level 1-7 }\end{array}$ & $45: 00 / 6: 31$ \\
\hline ELC 2 & Catalonia & 4 & $\begin{array}{l}\text { 5th-year student with double } \\
\text { major in Early Years Education } \\
\text { and Primary Education }\end{array}$ & $50: 00 / 6: 55$ \\
\hline
\end{tabular}

The picturebook On a Magical Do-Nothing Day was selected for this research project because it fulfilled some specific criteria that the two researchers had previously agreed upon. It should not be culturally specific to either of the two countries involved in this research. The reason for this is the idea that the book should not belong to the Norwegian or Catalan literary traditions to avoid an unbalanced cultural influence on the groups. To ensure the quality of the book the researchers wanted it to have been created by a celebrated artist. On a Magical Do-Nothing Day fulfilled both conditions because the work of Beatrice Alemagna has been described as a combination of "a rare depth of visual literacy with gentle, poetic humanity and a fearless approach to experimenting with media and materials" [32] (p. 66). Moreover, this title has received many awards (it received the Huckepack Prize (Germany) in 2019, the English Association Book Award in 2018, the Gold Medal of the Original Art Exhibition of the Society of Illustrators (USA) in 2017, the Grand Prix de l'Illustration (France) in 2017 and the Landerneau Prize (France) in 2017).

The book also seemed suitable for discussing a literary work from an ecocritical point of view because it fits the concept of "an environmentally oriented work," using Buell's definition [14]. He applies this term to work featuring a nonhuman environment in a way suggesting that human history is involved in natural history, while the human interest is not understood to be the only legitimate interest. In addition, human accountability to the environment is part of the text's ethical orientation and the environment is a process rather than something constant or given [14] (pp. 7-8).

Additionally, the plot seemed suitable for ELC because it contains many shifts, encounters, and visual details open to exploration and discussion: a boy with his mother in a holiday house on a rainy day, playing his video game, thinking about his missing father, urged by his mother to stop playing and spend some time outdoors. Having secretly brought his video game with him, his losing it in a pond forces him to approach his surroundings in a different way-exploring forgotten details in nature: snails, mushrooms, birds, mud, trees, and stones. He then returns home and reconnects with himself and his mother in silence. The fact that this story has a first person narrator also added an important value because readers are more involved in the story when a subjective voice is used and they are also easily placed in the story with a first-person narrator [33].

Well aware that no choice and no tool is neutral, it seems appropriate to justify the choice of Talkwall as a digital tool to collect the students' pre- and post-comments on the book and the ELC. Talkwall was chosen because it has been developed and designed in accordance with the principles 
of dialogic teaching to share exploratory talks (Talkwall was designed by the University of Oslo in cooperation with dialogic teaching researchers at Cambridge University). A central idea is that since all the written "contributions can be displayed on a large central screen or board, to be further organized and discussed [they] can be an exciting starting point for productive dialogues and the co-construction of knowledge" [34]. As Talkwall had been used in class before, students were familiar with it and they knew how to proceed when working with it. Using this tool had some clear advantages. Firstly, students were motivated about the activity because of the use of a digital tool. Secondly, having to make the effort to think about their comments on the picturebook, synthesize them, and express them in written words made students be concise and think independently. Finally, the timing was effective because they could quickly read their classmates' comments.

Ahead of the ELC-lesson, the two researchers discussed and designed the lesson, comprising the information letters, the reading process, and the instructions, through four Skype meetings (one hour each) and a shared Google document. As a preparation to the ELC-lesson, the students were introduced to ecocriticism in previous sessions by reading and discussing some scientific articles or book chapters on it. The Norwegian students read Goga [24,35], while the Catalan students read Pujol-Valls [36]. These articles were suitable because they analyse children's books ecocritically, so students could learn about this approach in a theoretical and practical way. They were also chosen because they were written in the students' mother tongues, so language understanding did not make text comprehension difficult.

The ELC-lesson was organized as a mix of reading aloud, displaying the picturebook on screen, or showing the double spreads to the students, reading stops with time to submit comments in relation to given instructions, and time to participate in an oral conversation (for a detailed schedule of the lesson, see Table 2 below). The instructions were developed in accordance with Curry's ideas about scaled reading and Langer's four stances of understanding literature $[29,30]$.

Table 2. Structure of ELC Lesson.

\begin{tabular}{|c|c|c|c|c|}
\hline What (Progress and Instructions) & Who & Tools & Material & $\begin{array}{c}\text { Time Spent } \\
\text { (Approx. Min.) }\end{array}$ \\
\hline $\begin{array}{l}\text { Book introduction: The book cover } \\
\text { was presented to the students } \\
\text { 1. Instructions: } \\
\text { Look closely at the cover and } \\
\text { indicate your thoughts and } \\
\text { expectations, e.g., I see ... , I think } \\
\ldots ., \text { I expect/believe ... (The aim of } \\
\text { the first instruction (I see...) was to } \\
\text { allow the student to step into the } \\
\text { book by looking at the cover. } \\
\text { The second instruction (I think ... ) } \\
\text { may help the student to make and } \\
\text { move through hypotheses about the } \\
\text { book when later discussing it with } \\
\text { peers. The third instruction (I expect } \\
\text {.. ) offered an opportunity to step } \\
\text { out and rethink one's own ideas } \\
\text { and, by discussing it with peers } \\
\text { later, also scale the reading to see } \\
\text { references to the discussion of } \\
\text { whether humans need to reconnect } \\
\text { with the environment to } \\
\text { create change). }\end{array}$ & Teacher-researcher & picturebook & written notes & $4-6$ \\
\hline Read aloud & teacher-researcher & picturebook & observation & 3 \\
\hline
\end{tabular}


Table 2. Cont.

\begin{tabular}{|c|c|c|c|c|}
\hline What (Progress and Instructions) & Who & Tools & Material & $\begin{array}{c}\text { Time Spent } \\
\text { (Approx. Min.) }\end{array}$ \\
\hline $\begin{array}{l}\text { Reading stop } \\
\text { 2. Instructions: Discuss with peers } \\
\text { and note down each other's } \\
\text { thoughts on the question indicated } \\
\text { by the narrator: how will I/he } \\
\text { manage without my/his } \\
\text { video game? }\end{array}$ & students & Talkwall & written notes & $5-6$ \\
\hline $\begin{array}{l}\text { Read aloud (the rest of } \\
\text { the picturebook) } \\
\text { (ELC2 made one more reading stop } \\
\text { to discuss in the group the } \\
\text { doublespread showing the world } \\
\text { upside down interpreting the } \\
\text { sentence "the whole world seemed } \\
\text { brand new" (the students adhered } \\
\text { to the Catalan translation reading } \\
\text { "Semblava que ho haguessin refet } \\
\text { tot de nou")). }\end{array}$ & teacher-researcher & picturebook & observation & 5 \\
\hline $\begin{array}{l}\text { Final discussion in group. } \\
\text { 3. Instructions: Discuss the last } \\
\text { page of the picturebook. How do } \\
\text { you interpret/understand this page } \\
\text { in the light of the book as a whole? }\end{array}$ & students & sound recorder & $\begin{array}{l}\text { transcribed } \\
\text { sound } \\
\text { recordings }\end{array}$ & $7-8$ \\
\hline $\begin{array}{l}\text { Post-reading } \\
\text { 4. Instruction: Go back to your first } \\
\text { notes and reflect upon them in the } \\
\text { light of what you experienced in the } \\
\text { group discussion } \\
\text { (The final instruction was developed } \\
\text { to facilitate a meta-perspective on } \\
\text { the ELC experience). }\end{array}$ & students & Talkwall & written notes & 5 \\
\hline
\end{tabular}

To be able to analyse the collected data we decided to use directed qualitative content analysis. In general, a content analysis is considered "a flexible method for analyzing text data" [37] (p. 1277). The goal of a directed qualitative content analysis "is to validate or extend conceptually a theoretical framework or theory. Existing theory or research can help focus the research question. It can provide predictions about the variables of interest or about the relationships among variables, thus helping to determine the initial coding scheme or relationships between codes" [37] (p. 1281). In line with this, we decided to use existing theory to identify key concepts as initial coding categories. Building on the theoretical framework and on the addressed research questions, we started the coding process with two sets of categories. A first set of categories dealt with dialogic competencies and was labelled "ability to critically engage with text" (critical thinking competency) and "ability to share and negotiate meaning" (collaboration competency). The second set dealt with ecocritical competencies and was labelled "comments on how nature is represented in words and illustrations," "comments on what role the physical setting plays in the plot," and "comments on whether the values expressed in the picturebook are consistent with ecological wisdom."

In accordance with the classic steps of the content analytical process [37] (p. 1285), we organized the final steps of the coding process in the following way: First, both researchers read and coded all the transcribed data, then we exchanged and cross-examined each other's coding. After discussing deviations or mismatches, we agreed upon the final coding categories. Finally, we reread the data and progressed to analysing the results of the coding process. Hsieh and Shannon state that "data that cannot be coded are identified and analysed later to determine if they represent a new category or 
a subcategory of an existing code" [37] (p. 1282). However, no new categories seemed necessary in this analysis.

Before presenting our findings it is worth noting that among the cons mentioned in relation to the use of a directed approach to content analysis are the facts that participants might get cues to answer in a certain way and that researchers might be more likely to find evidence that is supportive rather than non-supportive of a theory [37] (p. 1283). Hence, while analysing the material, we tried to take into consideration the fact that the students' ideas and discussion may be too directed by the lesson on ecocriticism and the word ecocritical in the information letter. In addition, we tried to be aware that our previous work on ecocriticism might influence our observations.

\section{Findings and Discussion}

The following presentation and discussion consist of two main parts: one dealing with dialogic competencies and one with ecocritical competencies.

\subsection{Dialogic Competencies}

The collected material includes several examples of students displaying dialogic competencies of both critically engaging with the text and negotiating and sharing ideas with peers. When analysing the data, it became clear that these competencies could be further divided into more nuanced dialogic competencies. Hence, we decided, first, to sort examples of students critically engaging with the text into examples of text-internal critical engagement and examples of text-external engagement. In what follows we will first present three different modes in which the text-internal kind of engagement appeared and two different ways in which the more distanced, text-external sort of engagement appeared in the collected data. In addition, the examples of how the students negotiated and shared their opinions about the text are grouped in three categories. Our findings related to these three categories will be presented afterward.

\subsubsection{Critically Engaging with the Text}

One mode that primarily occurred when the students were asked to present their thoughts about the book while using Talkwall was characterized by the use of adjectives. The adjectives were mainly used to describe and interpret specific elements in the illustrations, particularly the atmosphere of the place and the emotions of the character. A typical example would be when students stated that they saw "a calm landscape" (C) (from now on, (C) for Catalonia means ELC2 and (N) for Norway means ELC1), "a happy girl in a dark/grey forest on a foggy day" (N), or "a curious girl dressed in red" (N) (our italics). Judging by the cover, all students initially assumed that the main character was a girl. The Norwegian students became aware of the gender through the researcher's question "How do you think he will manage without his video game?" Like in the English translation, the Norwegian text has no linguistic indication of gender, while in the Catalan translation, gender is detectable through adjectives and participles that appear a few times in the text. Consequently, Catalan students became aware of the gender during the reading process. We found that the use of curious in regard to the character was rather frequent and recurring, but only in the group of Norwegian students. This may be due to a prominent idea in the Norwegian pedagogical discourse that children are curious by nature, and if not they should be encouraged to be.

A second mode is related to sentences that display an attempt to explain the reasons for what is happening or what can happen in the story. This cause and effect relationship is in line with Paul's [22] and Tung and Chang's [21] ideas about the abilities of critical thinkers. This way of engaging with the text is typically linked to the reading stop, where the students are asked to reflect upon how the boy will manage without his video game.

It is curious to note that while the Catalan students seem to unfold a more detailed reflection and frequently point out the feelings of the main character, the Norwegian students tend to make 
statements that give less attention to the reasons that led to the given interpretation and which focus on the actions and the place. The following two examples illustrate this point:

At first the girl will be sad, but as she gets up and walks she will embark on an adventure in the woods and it will be the first time she has experienced it, as she has never experienced such a thing before because of being addicted to the video game.

I think he gives up the video game and uses the woods as playground instead. He realizes that nature can be equally as fantastic. Perhaps he will act out the game in real life and not on screen.

Although one might speculate whether this difference has some cultural reason, the collected material is not extensive enough to draw any conclusions about this.

In addition to the two modes mentioned, we found that, although we directed the students towards expressions like I see, I think, I expect/believe in the way the tasks were presented, indicating actions of interpretation, there was also frequent use of such expressions in the group discussion and also some in the final reflection at the end of the ELC. Referring to Langer's [29] four stances of understanding literature, these expressions could be understood as examples of various stances of engagement. While one student's use of the word "imagine" could be an example of moving through the text ("Because he arrives, he looks at himself in the mirror, he sees his father, who I imagine was the most fearless, who encouraged him to go out and such" (C)), another student's use of "understood" could be an example of stepping out of the text ("The boy seemed curious already on the cover. I understood quite early that he would get away from the game" $(\mathrm{N}))$.

As shown, there are several examples of how the students critically engage with the text by moving through the text. Moreover, there are a few examples where the students display a more distant engagement coming from outside of the text. Some students use previous experience with picturebooks: "After listening to the reading, I noticed that sometimes the covers of storybooks, based on the elements they contain, can create an initial idea that then changes" (C). In other cases, students show critical thinking when stepping out of the text: "And the mother does not ask about the console, you know?, because maybe nowadays it would be like 'where is your console? Oh, they are very expensive, then you will buy the next one', you know?" (C).

\subsubsection{Negotiating the Meaning of the Text}

The act of negotiating meaning is especially present in the group discussions of the ELC. This aspect is detected in three different modes, which depend on the effects that the conversations have on the students' understanding.

Firstly, the act of meaning making is seen in these ELCs because students sometimes express that their understanding of the picturebook has changed thanks to the discussion with their classmates. This happens because the others make them aware of facts that initially went unnoticed. By thinking together, students have access to new interpretations of the book and, therefore, have more resources and information to position themselves critically. Examples of such awakenings may be the following two: "Ah, that's right, ah, of course" (C), and "Yes, that is a very clever point (YES) actually" (N). Similarly, the discussion also allows them to confirm that their interpretations are the same as their classmates':

At first I started thinking the same as Raquel and started with the same idea that the console was already sunk in the lake and then, if it is there, it is a signal that the boy is already having a good time and he has seen other things and is not missing it anymore. 
We discussed much the same [as what I had thought]. The discovery of nature and how immense, unfamiliar and fantastic. I had not thought anything about the comparison between the child, who is curious about nature because it is new. And the fishes, who are curious about the game because it is something they have never seen before.

Secondly, the dialogue can become a chain of comments that show that students agree and repeat, reformulate, or develop previous ideas. This shows that students create their own opinion and obtain knowledge when they exchange points of view. This mode is similar to the first one, but, whereas the first one is applied to specific comments that influence somebody's point of view, the second mode is rather a chain of interventions that is collectively developed. Both modes can be considered as "exploratory talk" because they are a kind of conversation where "everyone engages critically but constructively with each other's ideas" [26] (p. 16).

- $\quad$ (Student A) It's a bit weird.

- (Student B) Well, it's a weird arrival home, isn't it? Because he arrives, he looks at himself in the mirror, he sees his father, who I imagine was the most fearless, who encouraged him to go out and such.

- $\quad$ (Student A) At the beginning it says with whom he used to go ......

- $\quad$ (Student B) ... exploring. And when he returns, he sees his father, and the mother does not ask about it, she can already guess it, you know? (C)

- $\quad$ (Student C) That was the first step

- $\quad$ (Student D) ... to focus on and then she may take a break in a way

- $\quad$ (Student E) exactly (N)

In these two examples, it can also be seen how, in the construction of knowledge, students sometimes interrupt other students because they share the same ideas and want to participate in the explanation.

In these discussions, students sometimes directly ask about the others' opinions. In the Norwegian group, this happens twice: "We know rather little about the sea (MMM) does that mean anything?", "But why do you think that he is not telling the mother what he has experienced?" However, in the Catalan group, students only ask questions when they need help because they do not understand or remember what other students were saying: "What?, what? I do not understand your dream", "What else was it? I don't remember." Despite this difference, what both groups have in common is that speakers know that they can broaden their knowledge and understanding with their classmates' help. Through the process called co-construction, they "examine, in a critical way, any ideas offered and compare possible options for how they should proceed to a successful conclusion" [26] (p. 114).

Thirdly, students often use question tags or words asking for others' agreement: "And the mother does not ask about the console, you know?" (C). This implies that, while students express their opinion, they are aware that an audience is listening to them. This is arguably because they need their peers' approval of what they are expressing in order to continue speaking. The ones listening support them with approving sounds or confirming words: "I think that they finally had such a nice moment together [several YES's] and that he only wanted to enjoy it and perhaps absorb it a little [several WELL YES's]" $(\mathrm{N})$. The listeners want to express their approval so speakers know that the others share their opinion.

\subsection{Ecocritical Competencies}

To enable registration of the students' ecocritical competencies, we coded the students' Talkwall texts and the transcription of the group discussion with four different colours, each indicating a potential ecocritical competency. The most frequent competency was the one related to comments on how nature was represented in words and illustrations. Most of these comments were connected to 
the first instruction about the book cover. Another competency was related to the role of the physical setting in the plot. Examples of this competency seemed to be most frequent when the students discussed how the boy would manage without his video game. The other two competencies that we looked for in the students' texts and discussion were whether they saw any sign of an earth-centred approach or if values expressed in the picturebook were consistent with ecological wisdom. Evidence of such competencies were less frequent and mainly occurred in the group discussion and the students' final reflections. In the following, we will present each of the designated competencies separately, although the last two are explained together because of their scarcity.

\subsubsection{Nature in Words and Illustrations}

The category that refers to the way nature is represented in words and illustrations has the most examples. This may be because students were asked to describe and interpret the book in the first part of the lesson, although other elements identified later in their discussions have been classified under this category, too. For instance, the idea of treating nature as a playground resurfaces several times in the second half of the Norwegian session. The variety of appreciations detected in this corpus matches with the diverse concepts of nature adopted by kindergarten pre-service teachers in another research, which ranged from seeing nature as a static and pristine element to a dynamic, interactive, and systemic element [38]. When students were asked to describe what they could see on the cover, they focused on the graphic features. This focus could be related to the instructive verb "see," indicating that they should only look at visual elements. Many reported on natural elements such as a tree, a forest, a jungle, or garden, but also birds, bushes, and plants. Some mentioned more general concepts like nature, the landscape, the outdoors or aspects related to the climate-rain and fog. A few alluded to the child's interaction with the tree. As can be seen in the following example, the child was often described as having fun: "The girl is dressed in a red pullover and seems to be eager and happy" $(\mathrm{N})$. However, dark colours from the cover caught the eye of a couple of students, and one even expressed that those tones could represent a sad place: "It looks rather dark, therefore not very merry" $(\mathrm{N})$.

Despite this, when students hypothesized about what the book would be about, they did take the title into account: "I think the background of the cover represents the 'grey' day of nothing, and the girl in red represents something that may differ from this grey day" $(\mathrm{N})$. As this example shows, nature is depicted as something dark or grey but still something that the character happily engages with. This kind of appreciation has an impact on the way students articulate their hypotheses about the book. At this early stage in the ELC we found only one student referring to "the woods as playground" $(\mathrm{N})$. However, this idea will later be present in the rest of the session, especially in the reading stop. It is actually the most recurrent aspect in the reading stop from both groups. Although it could be predictable that the Norwegian students would pick up on this idea due to the strong ties between nature and play in the educational culture [39], the Catalan students also address this metaphor because the story invites the reader to see that the boy replaces the video game with other games when he starts interacting with nature.

The students focused on the fact that the child is literally in the woods: "I think he goes deeper into the woods" (N), but also emotionally, since the woods will replace and enrich his play: "At first she will be complaining and sad about losing it [the video game], but later she will realize that in the forest she can live her own adventure with the elements of nature" (C).

In the group discussion, the groups partially differed regarding the focus of their attention. The Catalan students, when occupied with nature, seemed to especially talk about water and the sea. This might be due to their being more familiar with and having their own experiences in relation to the sea, rather than in relation to the woods and mountains, as going to the beach is a very popular activity among Catalans in the summer.

The Norwegian students also discussed the sea, but they also referred to other natural elements such as snails, stones, and mushrooms. In addition, they more often pointed out the difference between outside and inside. A reason for this might be that Norwegians are very used to observing and enjoying 
nature, no matter whether it is at the seaside or inland. And they also place a lot of importance on having the possibility of spending time indoors or outdoors.

In the final reflections, the idea of the child's interaction with nature, which is seen as a playground, is repeated: "what really matters is seeing how a child enjoys, explores and discovers the forest" (C). This example and others prove that nature is understood as a place that needs to be discovered, an idea that is also present in the beginning of the session. In the end, nature is even seen as something more than just a fun place. It can be a magical place of wonders: "he has been able to enjoy and discover a fantastic and unreal world" (C).

\subsubsection{The Role of the Physical Setting in the Plot}

Several instructions asked the students to reflect on what the book was about and what they thought would happen at a specific point in the book (see Table 2, reading stop). When students, upon looking at the cover of the book, described what they saw or what they predicted would happen, some thought that nature would be a crucial place for the development of the story: "I think that this environment will be used by the girl to live her own adventure" (C). This idea of using the environment as a place for adventure was frequently referred to as "nature as playground" in the students' texts and final reflections. Some students also pointed out that the boy transfers his play with the video game to his play in nature, like this comment on how the boy would manage without his video game: "Although initially she would be sad and disappointed, once the rain would begin to stop, she would be able to create her own video game imagining that each different part of the forest is a new screen to overcome" $(\mathrm{N})$. There are a few statements showing the role of the physical environment in the setting in the group discussions. As has already been mentioned, a couple of students seem to note that the contrast between outdoor and indoor activities is significant to the plot, like when one of them suggests that the boy's outdoor activity changes him and that this change is also evident to the boy's mother: "Maybe she saw the changes in him (MMM), like when he returned home filthy" $(\mathrm{N})$.

\subsubsection{Ecological Wisdom}

Although we found rather few examples of students reporting on whether the values expressed in the picturebook were consistent with ecological wisdom, we consider those that we found to be significant. One may argue that the examples do not discuss ecological wisdom in its pure sense. Instead, the students seemed to express a sort of recognition of the importance of nature. Thus, in the students' remarks about the cover, there is little about ecological values. One of the Catalan students sees the place in the woods as a possible location where a "thousand enjoyable activities can be found." Similarly, one Norwegian student notes the forest could offer itself as a playground to the child, which is a predictable appreciation as has been argued above. Many statements appreciating nature can be found in the reading stop from both groups: "He realizes that nature can be equally fantastic" $(\mathrm{N})$. The students seem aware of the boy's possibilities to play in nature (before the character himself is): "At first she will be complaining and sad about losing it, but later she will realize that in the forest she can live her own adventure with the elements of nature. Then she realizes that, despite not having the video game, she is having a great time enjoying her free time" (C). This awareness of nature as a place of joy and wonder may be due to the teaching of ecocriticism ahead of the ELC, as this understanding is a "foundation of common knowledge to underpin their discussions" [26] (p. 112).

A recurrent theme in the group discussion is the contrast between the boy's play with the video game and his play in nature: "And, from the moment that the console has been left here, the boy can continue his life without using it and, in this way, see everything around him" (C). In the final reflections, almost all the students seem to pick up on this when they emphasize that the boy has opened "his eyes to the world around him" (C). Several of them mention that this change is linked to the contrast between the video game (technology) and experiences in nature. One claims that "he is always addicted to the screen of a video game and could not enjoy what is within his reach" (C). One student from each group refers to this as a moral lesson about what we may learn from 
nature or, as one of the Norwegian students concludes, "spend time with each other and with nature." Even though the examples are few, the above-cited ideas by the students could perhaps indicate that they have managed to engage ecocritically with the text and possibly display glimpses of cultural ecoliteracy, as explained by Gaard [19], when they consider video gaming less sustainable than playing with nature.

It is worth noting that one idea that appears many times in the Norwegian corpus is that the boy becomes aware or curious about what "nature could offer" $(\mathrm{N})$. The idea that nature may offer something to the boy or to humans in general is perhaps not consistent with ecological wisdom. On the contrary, one may claim that such a view is slightly anthropocentric and not aware of the possibility that humans may have something to offer to nature or a responsibility towards nature.

According to Glotfelty [16], ecocritical engagement with a text aims at taking an earth-centred approach. The majority of students did not adopt this perspective. Only a few examples appear in the corpus. The following was found in relation to the reading stop: "[she would be able to] experiment with nature, see what (she) can do with trees, with water, if (she) can create something, if (she) finds any animal to play with" (C). This student seems to suggest that the child in the book will connect with nature in ways that may rely on a mutual or holistic connectedness.

\section{Concluding Remarks}

This research was aimed at examining how Norwegian and Catalan student teachers express and negotiate their ideas about Beatrice Alemagne's picturebook On a Magical Do-Nothing Day in a teacher-researcher designed ELC. At the same time, this study also intended to investigate whether the ELC allowed these students to share ideas with others to build an analysis and understanding of the picturebook from an ecocritical point of view. In order to do this, dialogic and ecocritical competencies of the participants from both ELCs were studied.

Regarding the dialogic competencies, the focus has been on the use of critical thinking as shown through the readers' engagement, and also their willingness to discuss and negotiate meaning. Genuine critical engagement has been detected in text-internal reflections in three ways. The first one includes adjectives used to describe and interpret the cover of the book-especially for the illustration and as applied to the atmosphere of the place and the emotions of the character. The attribute curious was recurrent in the Norwegian group, which may have a cultural explanation. The second one is based on sentences suggesting a cause and effect relationship in the feelings of the main character, his actions, and the setting. The third one is focused on actions of interpretation that show that students engage with the text by moving through it or stepping out of it. Text-external reflections showing a more distanced engagement also appear in the collected data. This sometimes happens when the students, mainly the Catalan students, use previous experience with picturebooks.

In relation to the act of negotiating meaning, the group discussion is the part of the ELC when students debate on the meaning of the story more often. It has been shown that dialoguing can impact on students' reasoning in different ways. Their understanding of the picturebook can change or be enhanced thanks to new interpretations shared by their classmates. This act can become a chain of comments that collectively develops knowledge and opinions. When doing this, students sometimes interrupt each other to confirm points of view and they sometimes also ask questions to expand their knowledge and comprehension. Finally, students also show that they are aware of developing an idea together with other people when they use question tags or words asking for their peers' agreement, or when the listeners support speakers with approving sounds or confirming words.

Regarding the ecocritical competencies, the focus has been on the students' awareness of how nature is represented in words and illustrations, what role the physical setting plays in the plot, and of how the values expressed in the picturebook are potentially consistent with ecological wisdom. Students demonstrated substantial awareness of nature representations, especially when exploring the visual elements on the cover of the book. They also commented on the interaction between the child and the tree on the cover and already established at the start of the ELC an idea about nature as a 
playground. Their awareness of the setting and the idea of nature as a playground seemed to inform their ideas about the plot when indicating that something would happen to the child which would lead him to an adventure in nature. The students further referred to how the boy's outdoor experience and nature connectedness probably also altered his relationship with his mother.

Concerning the students' reflection on whether the book contained traits of a possible consistency with ecological wisdom, we found that such reflections primarily appeared as a result of sharing and negotiating ideas with peers. This is particularly valid in the students' remarks on and questioning of the shifting status of technology and nature in the boy's life. However, although the students could have adopted ecocritical terminology in their discussion, they only implicitly displayed their understanding of the concepts.

Based on these findings we can conclude that the literature conversation prepared and structured in line with ideas of dialogic teaching, ecocritical thinking, and literature didactics did encourage the students' critical engagement with and negotiation of representations of nature and ecological wisdom in the picturebook On a magical do-nothing day by Beatrice Alemagna. This study only reports on two ELCs with a limited number of students. Consequently, we are not able to conclude about the benefit of ELCs in general. Additionally, it only reports on one specific picturebook, but it can hopefully encourage other educators in both higher education and school to conduct ecocritical explorations of other books. For this to become an internalized practice that students take up in their own teaching, ELCs should be conducted in relation to more than one children's book. By repeated and further exploration through ELCs, students may experience differences both in the ways of structuring an ELC and in the ways nature and ecological wisdom are represented and transmitted in classic and contemporary children's literature.

Author Contributions: Conceptualization, N.G. and M.P.-V.; Data curation, N.G. and M.P.-V.; Formal analysis, N.G. and M.P.-V.; Investigation, N.G. and M.P.-V.; Methodology, N.G. and M.P.-V.; Project administration, N.G. and M.P.-V.; Resources, N.G. and M.P.-V.; Writing-original draft, N.G. and M.P.-V.; Writing-review \& editing, N.G. and M.P.-V. All authors have read and agreed to the published version of the manuscript.

Funding: This research received no external funding.

Conflicts of Interest: The authors declare no conflict of interest.

\section{References}

1. Gabrielsen, I.L.; Blikstad-Balas, M.; Tengberg, M. The role of literature in the classroom: How and for what purposes do teachers in lower secondary school use literary texts? L1 Educ. Stud. Lang. Lit. 2019, 19, 1-32. [CrossRef]

2. Colomer, T.; Munita, F. La experiencia lectora de los alumnos de Magisterio: Nuevos desafíos para la formación docente. Leng. Textos 2013, 38, 37-44.

3. Johansson, M. In I Texten Och Ut Ur Den-Nordiska Lärarstudenter Samtalar Om Lyrik. Educare Vetensk. Skr. 2019, 3, 62-86. [CrossRef]

4. Guanio-Uluru, L. Education for sustainability: Developing ecocritical literature circles in the student teacher classroom. Discourse Commun. Sustain. Educ. 2019, 10, 5-19.

5. Michelsen, P.A.; Fodstad Gourvennec, A.; Skaftun, A.; Sønneland, M. Samtalen som representasjon av teksten. In Norsk Litterær Årbok; Simonhjell, N., Jager, B., Eds.; Samlaget: Oslo, Norway, 2018; pp. 259-283.

6. Ananiadou, K.; Claro, M. 21st Century Skills and Competences for New Millennium Learners in OECD Countries; OECD Education Working Papers, No. 41.; OECD Publishing: Paris, France, 2009. [CrossRef]

7. Council of the European Union. Key Competences for Lifelong Learning. 2018. Available online: http://data.consilium.europa.eu/doc/document/ST-5464-2018-ADD-2/EN/pdf (accessed on 4 June 2020).

8. UNESCO. Education for Sustainable Development Goals Learning Objectives; UNESCO: Paris, France, 2017; Available online: http://unesdoc.unesco.org/images/0024/002474/247444e.pdf (accessed on 4 June 2020).

9. Servei d'Ocupació Curricular d'Educació Infantil i Primària (2017). Currículum Educació Primària; Generalitat de Catalunya: Barcelona, Spain, 2017. Available online: http://ensenyament.gencat.cat/web/.content/home/ departament/publicacions/colleccions/curriculum/curriculum-ed-primaria.pdf (accessed on 4 June 2020). 
10. The Norwegian Directorate for Education and Training. Core Curriculum—Values and Principles for Primary and Secondary Education. 2017. Available online: https://www.udir.no/lk20/overordnet-del/?lang=eng (accessed on 4 June 2020).

11. The Norwegian Directorate for Education and Training. Læreplan i Norsk. 2019. Available online: https://www.udir.no/lk20/nor01-06 (accessed on 4 June 2020).

12. Hermann-Wilmarth, J.M. More than book talks: Preservice teacher dialogue after reading gay and lesbian children's literature. Lang. Arts 2010, 87, 188-198.

13. Rueckert, W. Into and out of the void: Two essays. Iowa Rev. 1978, 9, 62-86. [CrossRef]

14. Buell, L. The Environmental Imagination: Thoreau, Nature Writing, and the Formation of American Culture; Belknap Press of Harvard University Press: Cambridge, MA, USA, 1995.

15. Glotfelty, C.; Fromm, H. (Eds.) The Ecocriticism Reader: Landmarks in Literary Ecology; University of Georgia Press: Athens, GA, USA, 1996.

16. Glotfelty, C. Introduction. In The Ecocriticism Reader: Landmarks in Literary Ecology; University of Georgia Press: Athens, GA, USA, 1996; pp. xv-xxxvii.

17. Garrard, G. Ecocriticism; Routledge: London, UK; New York, NY, USA, 2012.

18. Grimm, S. Ecodidactics? A German perspective. In Teaching Environments. Ecocritical Encounters; Bartosch, R., Grimm, S., Eds.; Peter Lang: Frankfurt am Main, Germany, 2014; pp. 247-259.

19. Gaard, G. Children's environmental literature: From ecocriticism to ecopedagogy. Neohelicon 2009, 36, 321-334. [CrossRef]

20. Alexander, R. Towards Dialogic Teaching: Rethinking Classroom Talk; Dialogos: Cambridge, UK, 2008.

21. Tung, C.A.; Chang, S.Y. Developing critical thinking through literature reading. Feng Chia J. Humanit. Soc. Sci. 2009, 19, 287-317.

22. Paul, R. Critical thinking: What, why, and how. New Dir. Community Coll. 1992, 77, 3-24. [CrossRef]

23. Aase, L. Litterære samtalar. In Kulturmøte i Tekstar. Litteraturdidaktiske Perspektiv; Nicolaisen, B.K., Aase, L., Eds.; Samlaget: Oslo, Norway, 2005; pp. 106-124.

24. Goga, N. Økokritiske litteratursamtaler. En arena for økt bevissthet om økologisk samspill? Acta Didact. 2019, 13. [CrossRef]

25. Mercer, N. Words \& Minds; Routledge: London, UK; New York, NY, USA, 2000.

26. Littleton, K.; Mercer, N. Interthinking: Putting Talk to Work; Routledge: London, UK, 2013.

27. Chambers, A. Tell Me; Stenhouse Publishers: York, ME, USA, 1996.

28. Daniels, H. Literature Circles: Voice and Choice. In Book Clubs and Reading Groups; Stenhouse Publishers: Portland, ME, USA, 2002.

29. Langer, J.A. Envisioning Literature: Literary Understanding and Literature Instruction; Teachers College Press: New York, NY, USA; Columbia University: London, UK, 1995.

30. Curry, A. A question of scale: Zooming out and zooming in on feminist ecocriticism. In The Edinburgh Companion to Children's Literature; Beauvais, C., Nikolajeva, M., Eds.; Edinburgh University Press: Edinburgh, UK, 2017; pp. 70-78.

31. Goga, N. "I felt like a tree lost in a storm"-The process of entangled knowing, becoming and doing in Beatrice Alemagna's picturebook Un Grande Giorno di Niente. In Plants in Children's and YA Literature; Guanio-Uluru, L., Duckworth, M., Eds.; Routledge: London, UK, (accepted).

32. Salisbury, M.; Styles, M. Children's Picturebooks. The Art of Visual Storytelling; Laurence King Publishing: London, UK, 2012.

33. May, J.P. Children's Literature and Critical Theory; Oxford University Press: New York, NY, USA; Oxford, UK, 1995.

34. Talkwall. Samtavla. Available online: https://talkwall.uio.no/\#/ (accessed on 4 June 2020).

35. Goga, N. Økofantasy. Frida Nilssons Ishavspirater. In Fantastisk Litteratur for Barn og Unge; Slettan, S., Ed.; Fagbokforlaget: Bergen, Norway, 2018; pp. 77-90.

36. Pujol-Valls, M. “Museu zoologic" i “Bestiari” de Josep Carner: Una aproximació ecocrítica. Caplletra 2023. (accepted).

37. Hsieh, H.-F.; Shannon, S.E. Three approaches to qualitative content analysis. Qual. Health Res. 2005, 15, 1277-1288. [CrossRef] [PubMed] 
38. Pérez-López, R.; Eugenio-Gozalbo, M.; Zuazagoitia, D.; Ruiz-González, A. Organic Learning Gardens in Higher Education: Do They Improve Kindergarten Pre-Service Teachers' Connectedness to and Conception of Nature? Front. Psychol. 2020, 11, 282. [PubMed]

39. The Norwegian Directorate for Education and Training. Framework Plan for Kindergartens. Available online: https://www.udir.no/globalassets/filer/barnehage/rammeplan/framework-plan-for-kindergartens22017.pdf (accessed on 24 June 2020).

(c)

(C) 2020 by the authors. Licensee MDPI, Basel, Switzerland. This article is an open access article distributed under the terms and conditions of the Creative Commons Attribution (CC BY) license (http://creativecommons.org/licenses/by/4.0/). 